ISSN 1392-3196 / e-ISSN 2335-8947

Zemdirbyste-Agriculture, vol. 107, No. 4 (2020), p. 291-300

DOI $10.13080 / \mathrm{z}-\mathrm{a} .2020 .107 .037$

\title{
The distribution of organic carbon, its forms and macroelements in agricultural soils
}

\author{
Alvyra SLEPETIENE ${ }^{1}$, Zydre KADZIULIENE ${ }^{1}$, Dalia FEIZIENE ${ }^{1}$, Inga LIAUDANSKIENE ${ }^{1}$, \\ Kristina AMALEVICIUTE-VOLUNGE ${ }^{1}$, Jonas SLEPETYS ${ }^{1}$, Aida SKERSIENE ${ }^{1}$, \\ Aleksandras VELYKIS ${ }^{2}$, Kestutis ARMOLAITIS ${ }^{3}$ \\ ${ }^{1}$ Lithuanian Research Centre for Agriculture and Forestry, Institute of Agriculture \\ Instituto 1, Akademija, Kèdainiai distr., Lithuania \\ E-mail: alvyra.slepetiene@lammc.lt \\ ${ }^{2}$ Lithuanian Research Centre for Agriculture and Forestry, Joniškèlis Experimental Station \\ Karpių 1, Joniškèlis, Pasvalys distr., Lithuania \\ ${ }^{3}$ Lithuanian Research Centre for Agriculture and Forestry, Institute of Forestry \\ Liepų 1, Girionys, Kaunas distr., Lithuania
}

\begin{abstract}
The objective of the present study was to estimate the distribution of soil organic carbon (SOC) and its forms (protected and labile organic carbon) and total nitrogen $\left(\mathrm{N}_{\text {tot }}\right)$, plant available phosphorus $\left(\mathrm{P}_{2} \mathrm{O}_{5}\right)$ and pottassium $\left(\mathrm{K}_{2} \mathrm{O}\right)$ within $0-30 \mathrm{~cm}$ layer of a ploughed horizon in agricultural soils as influenced by tillage and fertilisation. Research was carried out in two regions of Lithuania: in Central (sites I and II) and Northern (site III) parts of Middle Lithuanian Lowland. Tillage systems, including conventional tillage (CT) and no-tillage (NT), straw management methods and mineral fertilisation were investigated on a loam and sandy loam top layer of glacial morain Eutric Endocalcaric Endostagnic Cambisol in site I. Five fertilisation treatments were tested in a grassland with a sandy loam top layer of glacial morain Endocalcaric Albic Brunic Endogleyic Arenosol in site II: without fertilisation and fertilisation with separated liquid and separated solid digestates at rates of 85 and $170 \mathrm{~kg} \mathrm{ha}^{-1} \mathrm{~N}$. The field experiment on a glaciolacustrine Eutric Endocalcaric Amphistagnic Endogleyic Cambisol with clay loam in site III involved the following tillage systems: conventional tillage (CT), ploughless tillage (PT), ploughless tillage with lime sludge incorporation (PT + LS) and no-tillage with a cover crop for winter mulch (NT + WM). Long-term NT caused pronounced stratification of $\mathrm{N}_{\text {tot }}$, available $\mathrm{K}_{2} \mathrm{O}$ and SOC within the arable layer of Eutric Endocalcaric Endostagnic Cambisol. The highest accumulation of SOC and chemically protected-humified carbon in the grassland on an Endocalcaric Albic Brunic Endogleyic Arenosol was determined at the highest digestate rate of $170 \mathrm{~kg} \mathrm{ha}^{-1} \mathrm{~N}$. High SOC accumulation potential was shown by PT + LS in a Eutric Endocalcaric Amphistagnic Endogleyic Cambisol. This significantly increased the share of humified carbon fraction bound with calcium in 0-10 and 10-20 cm soil layers. Reduction of tillage intensity by applying PT and NT + WM increased the concentration of labile organic carbon in the soil, especially in the upper $0-10 \mathrm{~cm}$ layer. The lime sludge application reduced the amount of labile organic carbon by its incorporation with calcium in this amendment, while increasing the stability of carbon compounds. In Eutric Endocalcaric Endostagnic Cambisol, the mean results of 0-30 cm layer revealed that the share of F4 carbon fraction, resistant to degradation, in the SOC was significantly higher under NT than under CT.
\end{abstract}

Key words: digestate, fertilisation, labile and protected carbon, lime sludge, soil, tillage.

\section{Introduction}

Studies on the organic part of the soil were started more than 200 years ago, since it was already clear that soil organic matter (SOM) influenced plant growth, the vital physical and chemical properties of the soil, on which crop yields depend. SOM, whose main constituent is soil organic carbon (SOC), has been increasingly considered as an indicator of soil quality, one of the components of biosphere sustainability and stability (O'Rourke et al., 2015; Lal, 2018). The main functions of soil: biomass production, biodiversity stock, source of raw materials, storage, filtration and transformation of nutrients, materials and water, physical and cultural environment for humans, are directly dependent on the carbon stock. Forms of carbon (C) in the Earth's crust in the widest understanding can be divided into three groups: elemental $\mathrm{C}$ found in geological materials (graphite, coal) and as a product of incomplete combustion of organic matter (charcoal, graphite, soot); inorganic C geological or soil parent materials, usually as carbonates: calcite $\left(\mathrm{CaCO}_{3}\right)$, dolomite $\left(\mathrm{CaMg}\left(\mathrm{CO}_{3}\right)_{2}\right)$ and siderite

Please use the following format when citing the article:

Slepetiene A., Kadziuliene Z., Feiziene D., Liaudanskiene I., Amaleviciute-Volunge K., Slepetys J., Skersiene A., Velykis A., Armolaitis K. 2020. The distribution of organic carbon, its forms and macroelements in agricultural soils. Zemdirbyste-Agriculture, 107 (4): 291-300. DOI 10.13080/z-a.2020.107.037 
$\left(\mathrm{FeCO}_{3}\right)$, organic $\mathrm{C}$ - compounds of plant and animal origin at various stages of decomposition, ranging from $2 \mathrm{~mm}$ or more as crop residues, also plant debris referred to as particulate SOC with a size between 0.05 and $2 \mathrm{~mm}$, and humus - highly decomposed materials less than $0.05 \mathrm{~mm}$ that are dominated by molecules attached to soil minerals (Jakhar et al., 2017; Ondrasek et al., 2019). SOC research has become particularly relevant because of the necessity to look for ways to reduce $\mathrm{CO}_{2}$ emissions to the atmosphere by storing in the soil. Soils are known to have the unique and specific property to store large $\mathrm{C}$ quantities. They are estimated to contain about two to three times the amount of $\mathrm{C}$ stored in the atmosphere and vegetation in the total amount.

An increase in the global temperature because of radiative forcing of greenhouse gases (GHGs) in the atmosphere has been estimated at $0.6^{\circ} \mathrm{C}$ temperature during the $20^{\text {th }}$ century and is projected to be 1.4 to $5.8^{\circ} \mathrm{C}$ by 2100 relative to 1990 (IPCC, 2001). An increase in the atmospheric concentration of $\mathrm{CO}_{2}$ from $280 \mathrm{ppm}$ in 1750 to $367 \mathrm{ppm}$ in 1999 is attributed to emissions from fossil fuel combustion estimated at $270 \pm 30 \mathrm{Pg} \mathrm{C}$ and land use change at $136 \pm 55 \mathrm{Pg} \mathrm{C}$. Due to intensive management, soil has lost $78 \pm 12 \mathrm{Pg} \mathrm{C}$, which is estimated from depletion of SOC pool. Most agricultural soils have lost from $50 \%$ to $70 \%$ of their original SOC resources, and the depletion is extended by further soil degradation and desertification. The restoration of degraded soils, conversion of agriculturally marginal lands to appropriate land use and the adoption of recommended management practices on agricultural soils can reverse degradative trends and lead to SOC sequestration (Stockmann et al., 2013).

The capacity of soils to store organic C represents a key function of soils that is not only decisive for climate regulation but also affects other soil functions (Ondrasek et al., 2019; Wiesmeier et al., 2019). Concentrations and stocks of SOC depend on the genetic properties of the soil and its use as well as other factors. Soil C assessment in different parts of the world requires methods that are appropriate to the circumstances. The variety of methods that have been developed and tested for use in different countries raises concerns about their comparability. Ensuring this comparability warrants serious international priority. In the case of $\mathrm{C}$ projects, credible and cost-effective techniques of monitoring changes in soil $\mathrm{C}$ still need to be developed. The speed and accuracy of analytical methods are mostly dependent on the technical facilities available. Based on the results of laboratory studies, $\mathrm{C}$ models are developed to predict ways to preserve and maximize $\mathrm{C}$ accumulation, realize $\mathrm{C}$ accumulation and sequestration potential. In terms these processes, it is very important to monitor soil changes, even though, the implementation of soil monitoring networks poses several scientific, technical and operational challenges (Smith et al., 2020).

SOC accumulation in the soil has not been given enough attention in Lithuania. Episodic investigations of SOM were done in Lithuania more than three decades ago and were limited to the $0-20 \mathrm{~cm}$ layer. Currently, at the Institute of Agriculture, Lithuanian Research Centre for Agriculture and Forestry SOC and soil quality parameters were comprehensively studied in the soil of agricultural systems differing in intensity (Feiziene et al., 2011; 2016; 2018; Slepetiene et al., 2011; Bogužas et al., 2015; Volungevicius et al., 2018). Humus, like other key agrochemical indicators, was also investigated in the Lithuania (Mažvila et al., 2010). In addition, more detailed quantitative and qualitative humus investigations in long-term experiments are being conducted (Liaudanskiene et al., 2013; Amalevičiūtė et al., 2014; Jokubauskaite et al., 2015; Staugaitis et al., 2016; Feiziene et al., 2018). Some agronomic studies were carried out on the changes in $\mathrm{C}$ in the deeper soil layers and throughout the profile, but in most cases, they were episodic, small-scale, without establishing the relationship with $\mathrm{C}$ sequestration and emission. In collaboration with UK researchers, in the context of international research, it was also a great opportunity to compare the scientific achievements in SOC and SOM research worldwide with the achievements in Lithuania (Jankauskas et al., 2006 a; b).

In agricultural soils, SOC changes are intensive due to the constant changes in soil use, tillage, fertilisation, especially with intensive technologies (Leifeld et al., 2005; Paustian et al., 2016). Therefore, it is very important to assess the alterations in SOC accumulation in the soil (0-30 cm layer) occurring due to the changes in land use, e.g., conversion of grassland or pasture to arable land and vice versa. It has been established how much SOC is stored in different soil groups, i.e. on arable land, grasslands, pastures or forest. However, there is a lack of data about $\mathrm{C}$ stock changes in specific soil groups due to land use conversion.

The objective of the present study was to estimate the distribution of soil organic carbon (SOC) and its forms (protected and labile organic carbon) and total $\mathrm{N}\left(\mathrm{N}_{\text {tot }}\right)$, plant available phosphorus $\left(\mathrm{P}_{2} \mathrm{O}_{5}\right)$ and potassium $\left(\mathrm{K}_{2} \mathrm{O}\right)$ within 0-30 cm layer of a ploughed horizon in agricultural soils as influenced by tillage and fertilisation.

\section{Materials and methods}

Experimental sites, treatments and design. Research was carried out on agricultural soils in two regions: Central and Northern parts of Middle Lithuanian Lowland and three experimental sites of Lithuania.

Experimental site I: Akademija, Kédainiai district. The research area was situated in the Central part of Middle Lithuanian Lowland $\left(55^{\circ} 23^{\prime} 21.55^{\prime \prime} \mathrm{N}\right.$ $\left.23^{\circ} 52^{\prime} 09.50^{\prime \prime} \mathrm{E}\right)$. The data presented in this paper were collected from two long-term experiments on a glacial morain Eutric Endocalcaric Endostagnic Cambisol (Loamic, Aric, Drainic) according to WRB (2014). The investigations were carried out at Institute of Agriculture, Lithuanian Research Centre for Agriculture and Forestry in two three-factorial field experiments established in 1999 according to the same trial design. One of them was set up on a loam soil, and the other was established on a sandy loam textured ploughed Ap horizon. Both field experiments had a split-split-plot design with four replications. Straw management methods were the main plots, tillage systems - conventional tillage (CT) and no-tillage (NT) - were as sub-plots, and fertilisation according to soil properties and target yield was as split-split-plots. Fertilisation was the same for all tillage and straw management treatments. Moreover, in phosphorous-rich loam, $\mathrm{P}$ fertilisers were not used.

Experimental site II: Surviliškis (55²6'03.07"

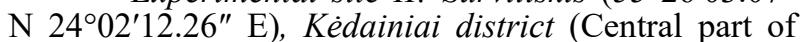
Middle Lithuanian Lowland), perennial grassland on a glacial morain Endocalcaric Albic Brunic Endogleyic Arenosol (Dystric) according to WRB (2014). The experiment including five fertilisation treatments was conducted in 2018: without fertilisation; fertilisation with separated liquid digestate 85 and $170 \mathrm{~kg} \mathrm{ha}^{-1} \mathrm{~N}$ and with separated solid digestate 85 and $170 \mathrm{~kg} \mathrm{ha}^{-1}$ $\mathrm{N}$, based on the results of the chemical analysis of the digestate. A randomised experimental design with three field replicates was used. A plot size was $6 \mathrm{~m}^{2}$. Dry and liquid digestate was spread on the grassland manually. 
The experiment was laid out on a semi-natural grassland, established 10 years ago.

Experimental site III: Joniškèlis, Pasvalys district. The soil of the research area is a glaciolacustrine Eutric Endocalcaric Amphistagnic Endogleyic Cambisol (Clayic, Aric, Drainic) according to WRB (2014) with a clay loam Ap horizon. Research was carried out in the field experiment, established in 2006 at the Joniškèlis Experimental Station of the Lithuanian Research Centre for Agriculture and Forestry situated in the Northern part of Middle Lithuanian Lowland $\left(56^{\circ} 02^{\prime} 19.23^{\prime \prime} \mathrm{N}\right.$ $\left.24^{\circ} 09^{\prime} 59.30^{\prime \prime} \mathrm{E}\right)$. This paper presents experimental data for the 2015-2017 period. Research design involved the following tillage systems: conventional (ploughing) tillage (CT), ploughless tillage (PT), ploughless tillage with lime sludge incorporation (PT + LS) and no-tillage with a cover crop for winter mulch (NT $+\mathrm{WM})$. The experiment was conducted in the crop rotation: field pea $\rightarrow$ winter wheat $\rightarrow$ spring oilseed rape $\rightarrow$ spring barley. Cover crops were as follows: before field pea growing - a mixture of white mustard and oilseed radish, before spring oilseed rape - a mixture of field pea and common vetch and before spring barley growing - oats. Lime sludge (Ca-amendment) $7 \mathrm{t} \mathrm{ha}^{-1}$ was incorporated three times per rotation for spring crops during the $1^{\text {st }}$ stage of the experiment (2007-2010), once per rotation for spring barley during the $2^{\text {nd }}$ stage of the experiment (2011-2014), and during the $3^{\text {rd }}$ stage of the experiment (2015-2018) lime sludge was not incorporated, but the effect of its previous incorporation was monitored. Straw of all crops was incorporated into the soil during tillage operations. The field experiment was arranged in a randomized single row design with four replicates.

Soil sampling. The soil samples in all experimental sites were collected annually from $0-10$, 10-20 and 20-30 cm depths of ploughed Ap horizon after the main crop harvesting. Six to eight sub-samples per plot were taken randomly with a steel auger. For each treatment and for each soil depth, soil samples were prepared in three replicates. The samples were air-dried, visible roots and plant residues were removed manually. Then the samples were crushed and sieved through a 2-mm sieve and homogeneously mixed.

Laboratory analyses were performed at the Chemical Research Laboratory of the Institute of Agriculture, Lithuanian Research Centre for Agriculture and Forestry. For the analysis of soil organic carbon (SOC), humic substances $\mathrm{C}$ and labile water extractable organic carbon an aliquot of the samples was passed through a $0.25-\mathrm{mm}$ sieve. The SOC content was determined by a spectrophotometric measurement at $590 \mathrm{~nm}$ after dichromatic oxidation and using glucose as a standard (Nikitin, 1999). The labile C content was determined by IR-detection after UV-catalysed persulfate oxidation. Soil clay fraction (particles $<2 \mu \mathrm{m}$ size) was isolated by the granulometric fractionation method of Schulz (2004) after sonication of soil aggregates. The $\mathrm{C}$ content in the clay fraction was determined by the Dumas method; the $\mathrm{C}$ content of the humus fractions was determined according to Ponomareva and Plotnikova (1980) modified Tyurin method. Chemodestructive fractionation for determination of easily oxidizable F1, $\mathrm{F} 2$, relatively stable $\mathrm{F} 3$ and resistant to degradation $\mathrm{F} 4$ fractions was performed according to the Popov and Tcyplenkov (1994) method, the procedure described in detail in Liaudanskienè et al. (2013). Total nitrogen $\left(\mathrm{N}_{\text {tot }}\right)$ content was determined by Kjeldahl method. The contents of plant available phosphorus $\left(\mathrm{P}_{2} \mathrm{O}_{5}\right)$ and potassium $\left(\mathrm{K}_{2} \mathrm{O}\right)$ were measured by extraction according to Egner-Riehm-Domingo (A-L) method. The acidity $(\mathrm{pH})$ of the soil was determined by the potentiometric method in $1 \mathrm{M} \mathrm{KCl}(1: 2.5, \mathrm{w} / \mathrm{v})$ extract. Soil bulk density was determined for estimating nutrient and SOC amount within different soil layers. Bulk density was assessed during implementation of complex sandbox method procedures (Klute, 1986). $\mathrm{P}_{2} \mathrm{O}_{5}(a)$ and $\mathrm{K}_{2} \mathrm{O}$ stocks (kg $\left.\mathrm{ha}^{-1}\right)$ were calculated as follows: concentration $\left(\mathrm{mg} \mathrm{kg}^{-1}\right)$ $\times$ bulk density $\left(\mathrm{t} \mathrm{m}^{-3}\right) \times 0.1 \mathrm{~m}$.

Statistical analysis. The data were analysed using the software $S A S$ Enterprice, version 7.1 (SAS Institute Inc., USA). The analysis of variance ( $A N O V A)$ was performed to determine the effects of management practices on soil chemical parameters, SOC content and its qualitative indices. The data were compared using Fisher's least significant difference (LSD) test at the probability levels of $P<0.05$ and $P<0.01$.

\section{Results and discussion}

Effect of soil management on SOC in morainic loam and sandy loam top layer. In loam, in the conventional tillage (CT) system straw removal caused $30 \%$ higher SOC stock within $0-30 \mathrm{~cm}$ soil layer than straw return. In no-tillage (NT) system this difference reached $24 \%$. Application of mineral fertilisers reduced this difference due to tillage and residue interactions (Table 1). However, NT had the advantage over CT. On average, NT superiority over CT for SOC sequestration in loam reached $8 \%$ on the background without residues and $13 \%$ on the background with residues.

In contrast to loam, in sandy loam, in the CT system straw removal caused $7 \%$ lower SOC content within 0-30 cm soil layer than straw return. Conversely, in the NT system SOC content on the background with residues decreased by $10 \%$, compared to residue removal (Table 1). NT had the advantage over CT only under residue removal. On average, NT superiority over CT for SOC sequestration on this background reached $4 \%$. However, under residue return, SOC sequestration was $16 \%$ higher in CT than NT.

Influence of tillage, fertilisation and straw management on soil chemical properties. Nutrient stratification is a typical feature under long-term NT management. On loam, long-term NT practice without fertilisation under straw removal caused pronounced stratification of $\mathrm{N}_{\text {tot }}$, available $\mathrm{K}_{2} \mathrm{O}$ and SOC within the arable layer. The ratios of each index between $0-10$ and $10-20 \mathrm{~cm}$ soil layers varied in the range of $1.08-1.39$. Furthermore, mineral fertiliser application in NT system under straw removal reduced these ratios by $4-12 \%$. Conversely, CT without fertilisation under residue removal resulted in higher content of $\mathrm{N}_{\text {tot }}$, available $\mathrm{P}_{2} \mathrm{O}_{5}$ and $\mathrm{K}_{2} \mathrm{O}$ and $\mathrm{SOC}$ in $10-20 \mathrm{~cm}$ than in $0-10 \mathrm{~cm}$ soil layer (Table 1). Crop fertilisation in the CT system under residue removal determined decrease of available $\mathrm{P}_{2} \mathrm{O}_{5}$ and $\mathrm{K}_{2} \mathrm{O}$ and SOC content within all arable layers, compared to unfertilised treatments, while stratification ratio changed fractionally.

Long-term NT practice under straw returning, irrespective of fertilisation, substantially increased only available $\mathrm{P}_{2} \mathrm{O}_{5}$ and $\mathrm{K}_{2} \mathrm{O}$ and SOC ratios between $0-10$ and $10-20 \mathrm{~cm}$ soil layers. However, CT practice without fertilisation under straw returning did not change noticeably the ratios of all indices between $0-10$ and 10 $20 \mathrm{~cm}$ soil layers, compared to the data on the background without residues. However, CT practice with fertilisation under straw returning significantly reduced the values of all indices in all soil layers (Table 1).

On sandy loam, after residue removal, CT without fertilisation resulted in higher concentration of $\mathrm{N}_{\text {tot }}$, available $\mathrm{P}_{2} \mathrm{O}_{5}$ and $\mathrm{K}_{2} \mathrm{O}$ in $10-20 \mathrm{~cm}$ than in $0-10 \mathrm{~cm}$ 
Table 1. Soil chemical parameters as influenced by long-term tillage, fertilisation and residue management in morainic loam and sandy loam Eutric Endocalcianc Endostagnic Cambisol (site I, 2016)

\begin{tabular}{|c|c|c|c|c|c|c|c|c|c|c|c|}
\hline \multirow{3}{*}{ Treatment } & \multirow{3}{*}{$\begin{array}{c}\text { Soil layer } \\
\mathrm{cm}\end{array}$} & \multicolumn{5}{|c|}{ Loam } & \multicolumn{5}{|c|}{ Sandy loam } \\
\hline & & \multirow{2}{*}{$\mathrm{pH}_{\mathrm{KCl}}$} & $\mathrm{N}_{\text {tot }}$ & $\mathrm{SOC}$ & $\mathrm{P}_{2} \mathrm{O}_{5}$ & $\mathrm{~K}_{2} \mathrm{O}$ & \multirow{2}{*}{$\mathrm{pH}_{\mathrm{KCl}}$} & $\mathrm{N}_{\text {tot }}$ & SOC & $\mathrm{P}_{2} \mathrm{O}_{5}$ & $\mathrm{~K}_{2} \mathrm{O}$ \\
\hline & & & \multicolumn{2}{|c|}{$\mathrm{t} \mathrm{ha}^{-1}$} & \multicolumn{2}{|c|}{$\mathrm{kg} \mathrm{ha}^{-1}$} & & \multicolumn{2}{|c|}{$\mathrm{t} \mathrm{ha}^{-1}$} & \multicolumn{2}{|c|}{$\mathrm{kg} \mathrm{ha}^{-1}$} \\
\hline & & & & & Straw & noved & & & & & \\
\hline \multirow{6}{*}{$\begin{array}{l}\text { CT without } \\
\text { fertilisers }\end{array}$} & $0-10$ & 7.03 & 1.88 & 17.2 & 465 & 291 & 5.90 & 1.60 & 13.2 & 161 & 153 \\
\hline & $10-20$ & 7.10 & 1.93 & 18.0 & 481 & 302 & 5.97 & 1.62 & 12.2 & 153 & 152 \\
\hline & $20-30$ & 7.10 & 1.67 & 16.6 & 482 & 299 & 5.93 & 1.33 & 12.4 & 155 & 166 \\
\hline & Mean 0-30 & & 1.83 & & 476 & & 5.93 & 1.52 & 12.6 & 156 & \\
\hline & $\Sigma 0-30$ & & $5.48 c$ & $51.8 \mathrm{~b}$ & $1427 b$ & $892 b$ & & $4.55 c$ & $37.8 d$ & $469 d$ & $471 d$ \\
\hline & $0-10: 10-20$ & 0.99 & 0.97 & 0.96 & 0.97 & 0.96 & 0.99 & 0.99 & 1.08 & 1.05 & 1.01 \\
\hline \multirow{6}{*}{$\begin{array}{l}\mathrm{CT}+\mathrm{NK} \\
\text { fertilisers }\end{array}$} & $0-10$ & 6.97 & 1.92 & 15.9 & 388 & 265 & 5.47 & 1.67 & 14.2 & 188 & 175 \\
\hline & $10-20$ & 7.10 & 1.90 & 17.1 & 372 & 278 & 5.47 & 1.75 & 13.0 & 194 & 181 \\
\hline & $20-30$ & 7.07 & 1.70 & 16.6 & 360 & 273 & 5.27 & 1.33 & 13.5 & 192 & 176 \\
\hline & Mean 0-30 & 7.04 & 1.84 & 16.5 & 373 & 272 & 5.40 & 1.58 & 13.6 & 191 & 177 \\
\hline & $\Sigma 0-30$ & & $5.52 b$ & $49.6 c$ & $1120 c$ & $817 c$ & & $4.75 b$ & $40.7 b$ & $574 c$ & $532 c$ \\
\hline & $0-10: 10-20$ & 0.98 & 1.01 & 0.93 & 1.04 & 0.95 & 1.00 & 0.95 & 1.09 & 0.97 & 0.97 \\
\hline \multirow{6}{*}{$\begin{array}{l}\text { NT without } \\
\text { fertilisers }\end{array}$} & $0-10$ & 7.20 & 2.10 & 20.0 & 526 & 357 & 5.80 & 1.89 & 14.2 & 142 & 141 \\
\hline & $10-20$ & 7.23 & 1.86 & 18.5 & 641 & 289 & 5.83 & 1.73 & 15.2 & 135 & 135 \\
\hline & $20-30$ & 7.30 & 1.35 & 17.1 & 573 & 271 & 5.77 & 1.30 & 13.1 & 135 & 138 \\
\hline & Mean 0-30 & 7.24 & 1.77 & 18.5 & 580 & 306 & 5.80 & 1.64 & 14.2 & 137 & 138 \\
\hline & $\Sigma 0-30$ & & $5.31 d$ & $55.6 a$ & $1739 a$ & $917 b$ & & $4.92 a$ & $42.6 a$ & $412 d$ & $414 e$ \\
\hline & $0-10: 10-20$ & 1.00 & 1.13 & 1.08 & 0.82 & 1.24 & 0.99 & 1.09 & 0.93 & 1.05 & 1.04 \\
\hline \multirow{6}{*}{$\begin{array}{l}\mathrm{NT}+\mathrm{NK} \\
\text { fertilisers }\end{array}$} & $0-10$ & 7.33 & 2.19 & 18.3 & 524 & 426 & 5.37 & 1.87 & 13.6 & 236 & 196 \\
\hline & 10 & 7.33 & 2.03 & 19.1 & 571 & 306 & 5.57 & 1.74 & 14.2 & 239 & 174 \\
\hline & $20-30$ & 7.40 & 1.52 & 16.0 & 565 & 255 & 5.73 & 1.28 & 11.3 & 182 & 170 \\
\hline & Mean 0-30 & 7.35 & 1.91 & 17.8 & 553 & 329 & 5.56 & 1.63 & 13.0 & 219 & 180 \\
\hline & $\Sigma 0-30$ & & $5.74 a$ & $53.6 \mathrm{~b}$ & $1660 a$ & $987 a$ & & $4.89 a$ & $39.1 \mathrm{c}$ & $657 b$ & $539 c$ \\
\hline & $0-10: 10-20$ & 1.00 & 1.08 & 0.96 & 0.92 & 1.39 & 0.96 & 1.07 & 0.96 & 0.99 & 1.13 \\
\hline \multicolumn{12}{|c|}{ Straw returned } \\
\hline \multirow{6}{*}{$\begin{array}{l}\text { CT without } \\
\text { fertilisers }\end{array}$} & $0-10$ & 6.70 & 1.86 & 13.4 & 324 & 224 & 6.20 & 1.51 & 14.3 & 174 & 180 \\
\hline & $10-20$ & 6.73 & 1.85 & 13.3 & 343 & 235 & 6.17 & 1.70 & 15.8 & 177 & 207 \\
\hline & $20-30$ & 6.70 & 1.51 & 11.3 & 380 & 280 & 6.27 & 1.33 & 13.1 & 195 & 196 \\
\hline & Mean 0-30 & 6.71 & 1.74 & 12.7 & 349 & 246 & 6.21 & 1.51 & 14.4 & 182 & 195 \\
\hline & $\Sigma 0-30$ & & $5.23 d$ & $38.0 e$ & $1048 c$ & $738 d$ & & $4.54 c$ & $43.2 a$ & $546 c$ & $584 b$ \\
\hline & $0-10: 10-20$ & 1.00 & 1.01 & 1.01 & 0.94 & 0.95 & 1.00 & 0.89 & 0.90 & 0.98 & 0.87 \\
\hline & $0-10$ & 6.53 & 1.79 & 12.8 & 250 & 238 & 6.17 & 1.65 & 13.7 & 245 & 212 \\
\hline & $10-20$ & 6.60 & 1.91 & 15.1 & 277 & 239 & 6.20 & 1.64 & 15.6 & 251 & 221 \\
\hline $\mathrm{CT}+\mathrm{NPK}$ & $20-30$ & 6.57 & 1.45 & 12.1 & 258 & 249 & 6.27 & 1.30 & 12.1 & 220 & 195 \\
\hline fertil & Mean 0-30 & 6.57 & 1.72 & 13.3 & 262 & 242 & 6.21 & 1.53 & 13.8 & 238 & 209 \\
\hline & $\Sigma 0-30$ & & $5.15 e$ & $40.0 d$ & $786 d$ & $726 d$ & & $4.58 c$ & $41.4 b$ & $715 a$ & $628 \mathrm{~b}$ \\
\hline & $0-10: 10-20$ & 0.99 & 0.94 & 0.85 & 0.90 & 1.00 & 1.00 & 1.01 & 0.88 & 0.98 & 0.96 \\
\hline & $\overline{0-1}$ & 6.83 & 2.03 & 15.2 & 329 & 246 & 5.87 & 1.72 & 12.3 & 152 & 164 \\
\hline & $10-2$ & 6.93 & 1.85 & 12.4 & 353 & 214 & 5.97 & 1.55 & 13.1 & 160 & 166 \\
\hline NT without & $20-30$ & 6.83 & 1.57 & 13.1 & 398 & 204 & 6.03 & 1.10 & 9.8 & 195 & 155 \\
\hline & Mean 0-30 & 6.86 & 1.82 & 13.6 & 360 & 221 & 5.96 & 1.46 & 11.8 & 169 & 162 \\
\hline & $\Sigma 0-30$ & & $5.45 c$ & $40.8 d$ & $1079 c$ & $664 e$ & & $4.37 d$ & $35.3 e$ & $506 d$ & $486 d$ \\
\hline & $0-10: 10-20$ & 0.99 & 1.10 & 1.23 & 0.93 & 1.15 & 0.98 & 1.11 & 0.94 & 0.95 & 0.99 \\
\hline & $0-10$ & 6.60 & 2.11 & 17.4 & 297 & 281 & 5.13 & 1.84 & 13.2 & 205 & 240 \\
\hline & & 6.73 & 1.95 & 15.2 & 274 & 192 & 5.10 & 1.68 & 13.3 & 218 & 264 \\
\hline $\mathrm{NT}+\mathrm{NPK}$ & $20-30$ & 6.77 & 1.53 & 14.8 & 282 & 190 & 5.47 & 1.29 & 11.4 & 160 & 220 \\
\hline fert & Mean 0-30 & 6.69 & 1.86 & 15.8 & 284 & 221 & 5.23 & 1.60 & 12.6 & 194 & 242 \\
\hline & $\Sigma 0-30$ & & $5.59 \mathrm{~b}$ & $47.4 c$ & $853 d$ & $663 e$ & & $4.81 a$ & $37.8 d$ & $583 c$ & $725 a$ \\
\hline & $0-10: 10-20$ & 0.98 & 1.08 & 1.14 & 1.08 & 1.46 & 1.01 & 1.10 & 0.99 & 0.94 & 0.91 \\
\hline
\end{tabular}

Note. CT - conventional tillage, NT - no-tillage, SOC - soil organic carbon; summarized data of each index, followed by the same letters are not significantly different at $p<0.05$.

soil layer (Table 1), while SOC content was higher in $0-10 \mathrm{~cm}$ than in 10-20 cm layer. Long-term NT caused pronounced stratification of $\mathrm{N}_{\text {tot }}$ and available $\mathrm{K}_{2} \mathrm{O}$ within arable layer, but SOC content was lower in $0-10 \mathrm{~cm}$ than in 10-20 cm soil layer. The SOC stratification ratio between the $0-10$ and $10-20 \mathrm{~cm}$ layers was 0.93 . Crop fertilisation with mineral NPK fertilisers in the CT system determined decrease of $\mathrm{N}_{\text {tot }}$, available $\mathrm{P}_{2} \mathrm{O}_{5}$ and $\mathrm{K}_{2} \mathrm{O}$ stratification ratio, compared to unfertilised treatments, while this ratio for SOC did not change. The analogous fertilisation in the NT system resulted in a decrease in $\mathrm{N}_{\text {tot }}$ and available $\mathrm{P}_{2} \mathrm{O}_{5}$ but had minor effect on other parameters within $0-20 \mathrm{~cm}$ soil layer.

After straw incorporation, under CT management, the stratification ratio of $\mathrm{N}_{\text {tot }}$, available $\mathrm{P}_{2} \mathrm{O}_{5}$ and $\mathrm{K}_{2} \mathrm{O}$ did not change noticeably, but stratification ratio of SOC significantly decreased, compared to the ratio on the background without residues. Under NT, this ratio significantly increased for $\mathrm{N}_{\text {tot }}$ and SOC, compared to the ratio on the background without crop residues.
Effect of soil management on SOC and agrochemical properties in glaciolacustrine clay loam. Soil $\mathrm{pH}$ in $0-10$ and $10-20 \mathrm{~cm}$ layers remained almost unchanged with CT and PT, but in $20-30 \mathrm{~cm}$ layer increased significantly to 6.04 with $\mathrm{CT}$ (Table 2). The effect of the former Ca-amendment with PT in the third rotation was strongly significantly increased in all three layers, and in the whole $0-30 \mathrm{~cm}$ layer $(\mathrm{pH}=6.69)$. In this soil management combination, also the greatest potential for $\mathrm{C}$ accumulation was observed: SOC increase in $0-10 \mathrm{~cm}$ layer was the highest and amounted to $26.13 \mathrm{t} \mathrm{ha}^{-1}$. Significant increase in available $\mathrm{P}_{2} \mathrm{O}_{5}$ was determined in PT, PT + LS and NT + WM in $0-10 \mathrm{~cm}$ soil layer.

SOC stability. More stable C compounds are less degradable and decompose more slowly. The degradation of SOC determines which SOC compounds remain in the soil and what interactions take place between them. An increase in SOC stock can partly offset the anthropogenic greenhouse gas (GHG) emissions (Lal, 2003; Paustian 
Table 2. Soil chemical parameters as influenced by tillage, Ca-amendment and cover crop in glaciolacustrine clay loam Eutric Endocalcaric Amphistagnic Endogleyic Cambisol (site III, 2017)

\begin{tabular}{|c|c|c|c|c|c|c|}
\hline \multirow{2}{*}{ Treatment } & \multirow{2}{*}{$\begin{array}{c}\text { Soil layer } \\
\mathrm{cm}\end{array}$} & \multirow{2}{*}{$\mathrm{pH}_{\mathrm{KCl}}$} & $\mathrm{N}_{\text {tot }}$ & $\mathrm{SOC}$ & $\mathrm{P}_{2} \mathrm{O}_{5}$ & $\mathrm{~K}_{2} \mathrm{O}$ \\
\hline & & & \multicolumn{2}{|c|}{$\mathrm{tha}^{-1}$} & \multicolumn{2}{|c|}{$\mathrm{kg} \mathrm{ha}^{-1}$} \\
\hline \multirow{5}{*}{$\mathrm{CT}$} & $0-10$ & 5.80 & 2.30 & 22.21 & 190.5 & 563.6 \\
\hline & $10-20$ & 5.80 & 2.30 & 22.28 & 213.0 & 545.4 \\
\hline & $20-30$ & 6.04 & 1.88 & 16.49 & 204.0 & 489.9 \\
\hline & Mean 0-30 & 5.87 & 2.16 & 20.33 & 202.5 & 533.0 \\
\hline & $0-10: 10-20$ & 1.00 & 1.00 & 1.00 & 0.89 & 1.03 \\
\hline \multirow{5}{*}{ PT } & $0-10$ & 5.92 & 2.42 & 25.38 & 286.5 & 595.8 \\
\hline & $10-20$ & 6.04 & 2.66 & 22.46 & 195.0 & 426.8 \\
\hline & $20-30$ & 6.12 & 1.73 & 15.75 & 126.0 & 371.6 \\
\hline & Mean 0-30 & 6.02 & 2.27 & 21.20 & 202.5 & 464.7 \\
\hline & $0-10: 10-20$ & 0.98 & 0.91 & 1.13 & 1.47 & 1.40 \\
\hline \multirow{5}{*}{$\mathrm{PT}+\mathrm{LS}$} & $0-10$ & 6.79 & 2.72 & 26.13 & 313.5 & 639.9 \\
\hline & $10-20$ & 6.84 & 2.27 & 21.98 & 198.0 & 498.8 \\
\hline & $20-30$ & 6.44 & 1.87 & 15.42 & 154.5 & 393.2 \\
\hline & Mean 0-30 & 6.65 & 2.28 & 21.17 & 222.0 & 510.6 \\
\hline & $0-10: 10-20$ & 0.99 & 1.20 & 1.19 & 1.58 & 1.28 \\
\hline \multirow{5}{*}{$\mathrm{NT}+\mathrm{WM}$} & $0-10$ & 5.83 & 2.73 & 25.75 & 231.0 & 661.8 \\
\hline & $10-20$ & 5.98 & 2.30 & 21.14 & 153.0 & 456.3 \\
\hline & $20-30$ & 6.14 & 1.75 & 13.65 & 144.0 & 394.4 \\
\hline & Mean 0-30 & 5.97 & 2.26 & 20.18 & 175.5 & 504.2 \\
\hline & $0-10: 10-20$ & 0.97 & 1.19 & 1.22 & 1.51 & 1.45 \\
\hline \multirow{4}{*}{$\mathrm{LSD}_{0.05}$} & $0-10$ & 0.28 & 0.16 & 1.64 & 21.33 & 67.72 \\
\hline & $10-20$ & 0.18 & 0.82 & 0.94 & 43.76 & 66.56 \\
\hline & $20-30$ & 0.22 & 0.15 & 1.00 & 45.07 & $\mathbf{5 7 . 4 3}$ \\
\hline & Mean 0-30 & 0.22 & 0.25 & 0.75 & 41.56 & 63.90 \\
\hline
\end{tabular}

Note. CT - conventional tillage, PT - ploughless tillage, PT + LS - ploughless tillage with lime sludge incorporation, NT + WM no-tillage with cover crop for winter mulch; SOC - soil organic carbon.

et al., 2016). But the questions addressed in a variety of scientific debates are about how much $\mathrm{C}$ stocks can be raised and what determines it? Feng (2012) suggested that further studies of the driving factors (e.g., chemical composition of organic $\mathrm{C}$ inputs, mineralogy, and organo-mineral binding types and strength) are needed to determine maximal $\mathrm{C}$ loadings and estimate the maximal soil C storage potential. The " 4 per 1,000 " initiative was launched at the COP21 Paris climate summit in 2015. It aims to boost $\mathrm{C}$ storage in agricultural soils by $0.4 \%$ each year to help mitigate climate change and increase food security (https://www.4p1000.org/). Despite the global importance of these societal imperatives, soil C sequestration is still not on the political agenda and was not formally discussed at the COP23 Bonn meeting in 2017. Crucially, the " 4 per 1,000" initiative will help governments to implement sustainable intensification of food production (Chabbi et al., 2017). Increased organic $\mathrm{C}$ sequestration in soil underpins several Sustainable Development Goals (SDGs) and directly contributes to SDG2 "Zero Hunger", SDG13 "Climate Action" and SDG15 "Life on Land" (https://www.nature.com).

The Earth's soil cover is one of the main reservoirs of organic $\mathrm{C}$ in the biosphere. The physical protection of SOC occurs in aggregates: SOC in most mineral soils is protected in aggregate interiors or through adsorption to mineral surfaces (Lehmann, Kleber, 2015), when relatively shallow-rooted agricultural ecosystems are converted to deep-rooted forests, root $\mathrm{C}$ inputs are introduced to deeper soil layers and can enhance or promote the decomposition of older SOC that was formerly protected under the agricultural ecosystem (Dijkstra, Cheng, 2007; Mobley et al., 2015).

In morainic loam, the mean results of F1, F2 and F3 fractions within the whole $0-30 \mathrm{~cm}$ soil layer were very similar in both $\mathrm{CT}$ and NT tillage systems, while percent of F4 fraction was higher under NT than under CT (Table 3). However, the distribution of chemodestructive fractions of SOC among different soil layers was unequal under tillage systems. NT caused slightly higher content of F2 (moderately labile C) within $0-10 \mathrm{~cm}$ layer and F4 (resistant C) within 10-20 cm layer, compared to CT. Consequently, loam response to different soil management for SOC stability was very similar.

Soil $\mathrm{C}$ distribution in chemodestructive fractions was more evident in sandy loam. In this soil, the mean results of the whole $0-30 \mathrm{~cm}$ layer revealed that $\mathrm{C}$ content in $\mathrm{F} 1, \mathrm{~F} 2$ and $\mathrm{F} 3$ fractions was lower under NT, while percent of F4 fraction was significantly higher under NT than under CT (Table 3). Consequently, longterm no-tillage management did not change $\mathrm{C}$ distribution in chemodestructive fractions within $0-10 \mathrm{~cm}$ layer apparently, compared to CT. However, it resulted in significantly higher SOC stability within 10-20 and 20$30 \mathrm{~cm}$ layers.

With the increase of SOC in the upper 0-10 cm glaciolacustrine clay loam layer due to the application of ploughless tillage and additional improving measures (Caamendment with lime sludge and cover crop for mulch), the proportion of easily oxidizable labile fractions ( $\mathrm{F} 1$ and F2) in the SOC also increased, compared to the CT (Table 4). Labile SOM compounds are biochemically most active, related to the transformation of matter and energy in the soil, thus affecting crop yield (Popov et al., 2004).

Chemically protected-humified carbon. Soil, which is a complex and continuously developing part of many ecosystems, plays an especially important role in the protection of natural environment and use of its resources for centuries (Six et al., 2002). The content of total SOC is not always a useful indicator for monitoring purposes, where the changes in land use are not drastic. In the last decades, more attention has been paid to the SOC of various lability (Schulz, 2004; Kolár et al., 2009), which has been acknowledged as a good indicator of soil quality and environmental health (Strosser, 2010). Carbon distribution in different fractions was reported by Six et al. (2002) and Sleutel et al. (2006). The results of our experiment show the distribution of $\mathrm{C}$ 
Table 3. Soil organic carbon (SOC) distribution in chemodestructive fractions in morainic loam and sandy loam Eutric Endocalcaric Endostagnic Cambisol (site I, 2017)

\begin{tabular}{|c|c|c|c|c|c|}
\hline \multirow{2}{*}{ Tillage system } & \multirow{2}{*}{$\begin{array}{l}\text { Soil depth } \\
\mathrm{cm}\end{array}$} & \multicolumn{4}{|c|}{$\mathrm{C}$ of chemodestructive fractions, in $\%$ of SOC } \\
\hline & & F1 & F2 & F3 & F4 \\
\hline \multicolumn{6}{|c|}{ Loam } \\
\hline \multirow{4}{*}{ Conventional tillage (CT) } & $0-10$ & 46.45 & 12.40 & 15.27 & 25.88 \\
\hline & $10-20$ & 48.02 & 14.31 & 17.22 & 20.45 \\
\hline & $20-30$ & 44.77 & 14.44 & 19.77 & 21.03 \\
\hline & Mean 0-30 & 46.41 & 13.72 & 17.42 & 22.45 \\
\hline \multirow{4}{*}{ No-tillage (NT) } & $0-10$ & 46.82 & 13.83 & 14.53 & 24.83 \\
\hline & $10-20$ & 45.76 & 11.99 & 16.10 & 26.14 \\
\hline & $20-30$ & 45.99 & 13.56 & 19.35 & 21.09 \\
\hline & Mean 0-30 & 46.19 & 13.13 & 16.66 & 24.02 \\
\hline \multicolumn{6}{|c|}{ Sandy loam } \\
\hline \multirow{4}{*}{ CT } & $0-10$ & 44.69 & 10.03 & 15.43 & 29.85 \\
\hline & $10-20$ & 43.47 & 12.72 & 15.20 & 28.61 \\
\hline & $20-30$ & 40.65 & 10.98 & 16.16 & 32.22 \\
\hline & Mean 0-30 & 42.94 & 11.24 & 15.60 & 30.23 \\
\hline \multirow{4}{*}{ NT } & $0-10$ & 41.91 & 11.47 & 10.88 & 35.74 \\
\hline & $10-20$ & 38.10 & 9.092 & 15.10 & 37.71 \\
\hline & $20-30$ & 35.55 & 11.91 & 14.13 & 38.41 \\
\hline & Mean $0-30$ & 38.52 & 10.82 & 13.37 & 37.29 \\
\hline
\end{tabular}

F1 - labile, F2 - moderately labile, F3 - stable, F4 - resistant fractions

Table 4. Soil organic carbon (SOC) distribution in chemodestructive fractions in glaciolacustrine clay loam Eutric Endocalcaric Amphistagnic Endogleyic Cambisol (site III, 2016)

\begin{tabular}{|c|c|c|c|c|c|}
\hline \multirow{2}{*}{ Tillage system } & \multirow{2}{*}{$\begin{array}{l}\text { Soil depth } \\
\mathrm{cm}\end{array}$} & \multicolumn{4}{|c|}{$\mathrm{C}$ of chemodestructive fractions, in $\%$ of SOC } \\
\hline & & F1 & F2 & F3 & F4 \\
\hline \multirow{4}{*}{ CT } & $0-10$ & 48.64 & 12.75 & 26.72 & 11.89 \\
\hline & $10-20$ & 52.01 & 15.87 & 18.33 & 11.09 \\
\hline & $20-30$ & 65.73 & 13.87 & 10.73 & 17.92 \\
\hline & Mean $0-30$ & 55.46 & 14.16 & 18.59 & 14.53 \\
\hline \multirow{4}{*}{ PT } & $0-10$ & 52.23 & 12.73 & 18.96 & 16.08 \\
\hline & $10-20$ & 47.50 & 14.97 & 18.48 & 19.04 \\
\hline & $20-30$ & 45.91 & 14.03 & 22.29 & 17.76 \\
\hline & Mean $0-30$ & 48.55 & 13.91 & 19.91 & 17.63 \\
\hline \multirow{4}{*}{$\mathrm{PT}+\mathrm{LS}$} & $0-10$ & 49.45 & 13.28 & 23.08 & 14.18 \\
\hline & $10-20$ & 50.59 & 14.03 & 20.02 & 15.37 \\
\hline & $20-30$ & 48.59 & 12.96 & 23.57 & 14.87 \\
\hline & Mean $0-30$ & 40.57 & 13.42 & 22.22 & 14.01 \\
\hline \multirow{4}{*}{$\mathrm{NT}+\mathrm{WM}$} & $0-10$ & 50.65 & $\frac{15.42}{12.28}$ & 18.62 & 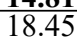 \\
\hline & $10-20$ & 48.12 & 13.85 & 22.77 & 15.25 \\
\hline & $20-30$ & 49.74 & 13.23 & 25.31 & 11.73 \\
\hline & Mean 0-30 & 49.50 & 13.12 & 22.23 & 15.14 \\
\hline
\end{tabular}

CT - conventional tillage, PT - ploughless tillage, PT + LS - ploughless tillage with lime sludge incorporation, NT + WM - notillage with cover crop for winter mulch; F1 - labile, F2 - moderately labile, F3 - stable, F4 - resistant fractions

in humified fractions using different tillage systems and soil amendments in clay loam soil (Table 5). The best combination of soil management for SOC accumulation potential was PT + LS, which significantly increased the fraction of humified $\mathrm{C}$ bound with $\mathrm{Ca}$ in $0-10$ and 10 $20 \mathrm{~cm}$ layers, compared to CT.

Mobile fulvic acids usually dominate in loam and sandy loam soil. They are less valuable than humic acids, and their content was $2.29 \mathrm{~g} \mathrm{~kg}^{-1}$ in no fertilised treatment in the soil having cambic properties Endocalcaric Albic Brunic Endogleyic Arenosol (Table 6 ). The amount of mobile humic acids (MHA) tended to increase to $2.32-2.46 \mathrm{~g} \mathrm{~kg}^{-1}$ in $0-10 \mathrm{~cm}$ layer after fertilisation with the highest rate $\left(170 \mathrm{~kg} \mathrm{ha}^{-1} \mathrm{~N}\right)$ of solid and liquid digestate. When using all types and rates of digestate as a biofertiliser, this increase was 36-45\% higher in $20-30 \mathrm{~cm}$ layer, compared to CT.

Labile organic carbon. Water extractable organic $\mathrm{C}$ is one of the labile, most rapidly changing forms of active C. Many studies (Geraei et al., 2016; Jokubauskaite et al., 2016; Awale et al., 2017; Slepetiene et al., 2017; Volungevičius etal., 2019) have used labile organic $\mathrm{C}$ to assess the impact of agricultural management and land use change on soil quality. The data presented in Figures 1 and 2 show that the $\mathrm{C}$ contents of the labile fraction were relatively small in Cambisols $-0.205-0.307 \mathrm{~g} \mathrm{~kg}^{-1}$ in $0-10 \mathrm{~cm}$, and in the deeper soil layers they were even smaller. The greater part of SOC is present in insoluble forms in most soils, except for a small fraction, and labile $\mathrm{C}$, which is determined by measuring the $\mathrm{C}$ content of aqueous extracts using sensitive laboratory equipment. Labile organic $\mathrm{C}$ constitutes a small part of the total SOC; however, it is the most mobile and reactive soil $\mathrm{C}$ pool that influences the physical, chemical and biological processes occurring in the soil.

On loamy textured Cambisol, on background without straw, $\mathrm{C}$ content in labile fractions within $0-10 \mathrm{~cm}$ layer varied from $0.345 \mathrm{~g} \mathrm{~kg}^{-1}$ under NT management to $0.379 \mathrm{~g} \mathrm{~kg}^{-1}$ under CT. In $10-20 \mathrm{~cm}$ layer, in the CT system, labile organic C content did not change, compared to the top-soil layer, while in NT system it decreased by $11 \%$. In $20-30 \mathrm{~cm}$ layer, labile organic $\mathrm{C}$ content became $15 \%$ lower, compared to the top-soil layer under both tillage systems.

Straw returning reduced labile organic $\mathrm{C}$ by $16 \%$ in the NT system and by $35 \%$ in the CT system within the whole $0-30 \mathrm{~cm}$ layer. On the background with straw, $\mathrm{C}$ content in labile fractions within $0-10 \mathrm{~cm}$ layer varied from $0.252 \mathrm{~g} \mathrm{~kg}^{-1}$ under CT to $0.304 \mathrm{~g} \mathrm{~kg}^{-1}$ under NT. In 10-20 cm layer, in CT, labile organic C content did not change noticeably, compared to the top-soil layer, while in NT system it decreased by $16 \%$. In $20-30 \mathrm{~cm}$ layer, labile organic C content decreased by $19 \%$ in CT and by $24 \%$ in NT, compared to the top-soil layer. 
Table 5. Soil organic carbon (SOC) distribution in humified fractions in glaciolacustrine clay loam Eutric Endocalcaric Amphistagnic Endogleyic Cambisol (site III, average of 2015-2016)

\begin{tabular}{|c|c|c|c|c|}
\hline \multirow[b]{2}{*}{ Tillage system } & \multirow{2}{*}{$\begin{array}{c}\text { Soil layer } \\
\mathrm{cm}\end{array}$} & \multicolumn{3}{|c|}{ Share of humified carbon, in $\%$ of SOC } \\
\hline & & mobile & $\begin{array}{c}\text { stabilized by } \\
\mathrm{Ca}\end{array}$ & $\begin{array}{l}\text { stabilized by } \\
\text { clay minerals }\end{array}$ \\
\hline \multirow{4}{*}{ CT } & $0-10$ & 13.07 & 15.86 & 31.22 \\
\hline & $10-20$ & 13.03 & 16.78 & 31.17 \\
\hline & $20-30$ & 12.88 & 17.70 & 31.16 \\
\hline & Mean $0-30$ & 12.99 & 16.78 & 31.18 \\
\hline \multirow{4}{*}{ PT } & $0-10$ & 12.85 & 16.11 & 30.94 \\
\hline & $10-20$ & 12.59 & 16.55 & 30.76 \\
\hline & $20-30$ & 12.05 & 17.20 & 30.60 \\
\hline & Mean $0-30$ & 12.50 & 16.62 & 30.77 \\
\hline \multirow{4}{*}{$\mathrm{PT}+\mathrm{LS}$} & $0-10$ & 11.50 & 16.98 & 31.79 \\
\hline & $10-20$ & 11.59 & 17.97 & 31.42 \\
\hline & $20-30$ & 11.82 & 18.46 & 30.97 \\
\hline & Mean 0-30 & 11.64 & 17.80 & 31.39 \\
\hline \multirow{4}{*}{$\mathrm{NT}+\mathrm{WM}$} & $0-10$ & 13.36 & 15.42 & 30.98 \\
\hline & $10-20$ & 13.16 & 16.41 & 30.73 \\
\hline & $20-30$ & 12.96 & 17.83 & 30.55 \\
\hline & Mean 0-30 & 13.16 & 16.55 & 30.77 \\
\hline \multirow{4}{*}{$\mathrm{LSD}_{05}$} & $0-10$ & 0.868 & 0.961 & 1.230 \\
\hline & $10-20$ & 0.873 & 0.934 & 1.394 \\
\hline & $20-30$ & 0.890 & 0.942 & 1.295 \\
\hline & Mean 0-30 & 0.877 & 0.945 & 1.306 \\
\hline
\end{tabular}

CT - conventional tillage, PT - ploughless tillage, PT + LS - ploughless tillage with lime sludge incorporation, NT + WM - notillage with cover crop for winter mulch

Table 6. Soil organic carbon (SOC) and humified C content as influenced by fertilisation with digestate in glacial morain Endocalcaric Albic Brunic Endogleyic Arenosol (site II, 2018)

\begin{tabular}{|c|c|c|c|c|c|c|c|}
\hline \multirow{2}{*}{\multicolumn{2}{|c|}{ Treatment }} & \multirow{2}{*}{$\begin{array}{c}\text { Soil layer } \\
\mathrm{cm}\end{array}$} & $\mathrm{SOC}$ & C-MHS & C-MHA & C-MHS & C-MHA \\
\hline & & & \multicolumn{3}{|c|}{$\mathrm{g} \mathrm{kg}^{-1}$} & \multicolumn{2}{|c|}{$\%$ to control } \\
\hline \multirow{4}{*}{\multicolumn{2}{|c|}{$\begin{array}{l}\text { Control } \\
\text { (no fertiliser) }\end{array}$}} & $0-10$ & 11.77 & 3.94 & 2.29 & 100 & 100 \\
\hline & & $10-20$ & 8.40 & 2.71 & 2.30 & 100 & 100 \\
\hline & & $20-30$ & 4.00 & 1.05 & 0.53 & 100 & 100 \\
\hline & & Mean 0-30 & 8.06 & 2.57 & 1.71 & 100 & 100 \\
\hline \multirow{4}{*}{\multicolumn{2}{|c|}{$\begin{array}{l}\text { Liquid digestate } \\
85 \mathrm{~kg} \mathrm{ha}^{-1} \mathrm{~N}\end{array}$}} & $0-10$ & 13.07 & 4.01 & 2.31 & 102 & 101 \\
\hline & & $10-20$ & 8.70 & 2.92 & 1.29 & 108 & 56 \\
\hline & & $20-30$ & 4.70 & 1.50 & 0.72 & 143 & 136 \\
\hline & & Mean 0-30 & 8.82 & 2.81 & 1.44 & 109 & 84 \\
\hline \multirow{4}{*}{\multicolumn{2}{|c|}{$\begin{array}{l}\text { Liquid digestate } \\
170 \mathrm{~kg} \mathrm{ha}^{-1} \mathrm{~N}\end{array}$}} & $0-10$ & 13.37 & 4.02 & 2.46 & 102 & 107 \\
\hline & & $10-20$ & 9.80 & 3.06 & 2.46 & 113 & 107 \\
\hline & & $20-30$ & 4.30 & 1.36 & 0.73 & 130 & 138 \\
\hline & & Mean 0-30 & 9.16 & 2.81 & 1.88 & 109 & 110 \\
\hline \multirow{4}{*}{\multicolumn{2}{|c|}{$\begin{array}{l}\text { Solid digestate } \\
85 \mathrm{~kg} \mathrm{ha}^{-1} \mathrm{~N}\end{array}$}} & $0-10$ & 12.83 & 4.22 & 2.28 & 107 & 100 \\
\hline & & $10-20$ & 9.33 & 3.24 & 1.82 & 120 & 79 \\
\hline & & $20-30$ & 4.57 & 1.50 & 0.77 & 143 & 145 \\
\hline & & Mean 0-30 & 8.91 & 2.99 & 1.62 & 116 & 95 \\
\hline \multirow{8}{*}{$\begin{array}{l}\text { Solid digestate } \\
170 \mathrm{~kg} \mathrm{ha}^{-1} \mathrm{~N}\end{array}$} & & $0-10$ & 13.53 & 4.21 & 2.32 & 107 & 101 \\
\hline & & $10-20$ & 8.83 & 3.15 & 1.74 & 116 & 76 \\
\hline & & $20-30$ & 4.23 & 1.51 & 0.73 & 177 & 138 \\
\hline & & Mean 0-30 & 8.86 & 2.96 & 1.60 & 115 & 94 \\
\hline & \multirow{4}{*}{$\mathrm{LSD}_{05}$} & $0-10$ & 2.91 & 0.822 & 0.411 & & \\
\hline & & $10-20$ & 3.20 & 0.897 & 0.460 & & \\
\hline & & $20-30$ & 2.93 & 0.921 & 0.460 & & \\
\hline & & Mean 0-30 & 3.01 & 0.880 & 0.444 & & \\
\hline
\end{tabular}

C-MHS - carbon of mobile humic substances, C-MHA - carbon of mobile humic acids

On sandy loamy Cambisol, on the background without straw, C content in labile fractions within $0-10 \mathrm{~cm}$ layer varied from $0.337 \mathrm{~g} \mathrm{~kg}^{-1}$ under NT to $0.371 \mathrm{~g} \mathrm{~kg}^{-1}$ under CT. In 10-20 cm layer, in CT, labile organic C content decreased by $24 \%$, in NT by $12 \%$, compared to the top-soil layer. In 20-30 cm layer, labile organic C content decreased by $34 \%$ in CT and by $26 \%$ in NT, compared to the top-soil layer.

In contrast to loam, straw returning did not change labile organic $\mathrm{C}$ under NT but reduced its content by $25 \%$ in $\mathrm{CT}$ within the whole $0-30 \mathrm{~cm}$ layer. On the background with straw, $\mathrm{C}$ content in labile fractions within 0-10 cm layer varied from $0.296 \mathrm{~g} \mathrm{~kg}^{-1}$ under CT to $0.363 \mathrm{~g} \mathrm{~kg}^{-1}$ under NT. In 10-20 cm layer, in CT, labile organic C content slightly increased (by $3 \%$ ), compared to the top-soil layer, while in NT it decreased by $9 \%$. In 20 $30 \mathrm{~cm}$ layer, labile organic $\mathrm{C}$ content decreased by $23 \%$ in $\mathrm{CT}$ and by $28 \%$ in NT, compared to the top-soil layer.

Labile organic $\mathrm{C}$ fractions are more sensitive to changes in soil management. The results of our experiment showed that with decreasing tillage intensity in clay loam Cambisol the concentration of labile organic $\mathrm{C}$ in the soil, especially in the upper $0-10 \mathrm{~cm}$ layer, increased by $0.307 \mathrm{~g} \mathrm{~kg}^{-1}$ in the ploughless tillage treatment and by $0.305 \mathrm{~g} \mathrm{~kg}^{-1}$ in the no-tillage with a cover crop for winter mulch treatment (Fig. 2). Concentrations of labile organic $\mathrm{C}$ decreased with increasing soil depth. Lime sludge increased the stability of carbon by decreasing the amount of labile organic $\mathrm{C}$. 
Morainic loam

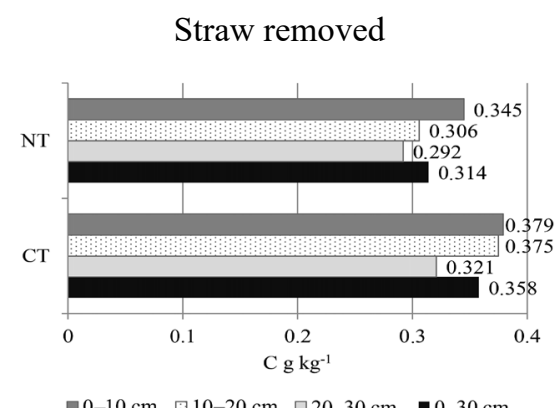

$\square 0-10 \mathrm{~cm} \square 10-20 \mathrm{~cm} \quad \square 20-30 \mathrm{~cm} \quad \square 0-30 \mathrm{~cm}$

Straw removed

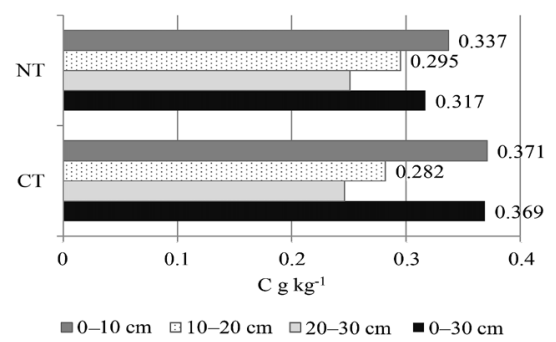

Straw returned

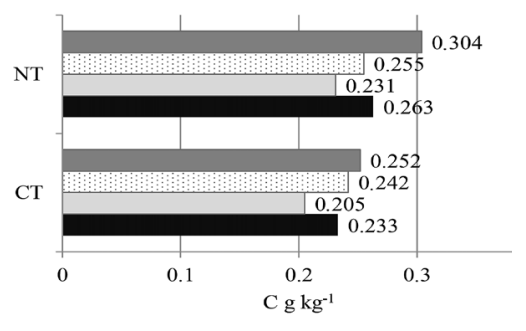

$\square 0-10 \mathrm{~cm} \quad \square 10-20 \mathrm{~cm} \quad \square 20-30 \mathrm{~cm} \quad \square 0-30 \mathrm{cn}$

Sandy loam

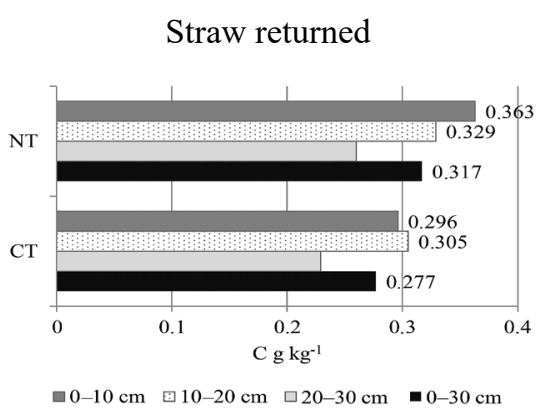

NT - no-tillage, CT - conventional tillage

Figure 1. The influence of soil management on labile organic carbon content in morainic loam and sandy loam Eutric Endocalcianc Endostagnic Cambisol (site I, 2017)

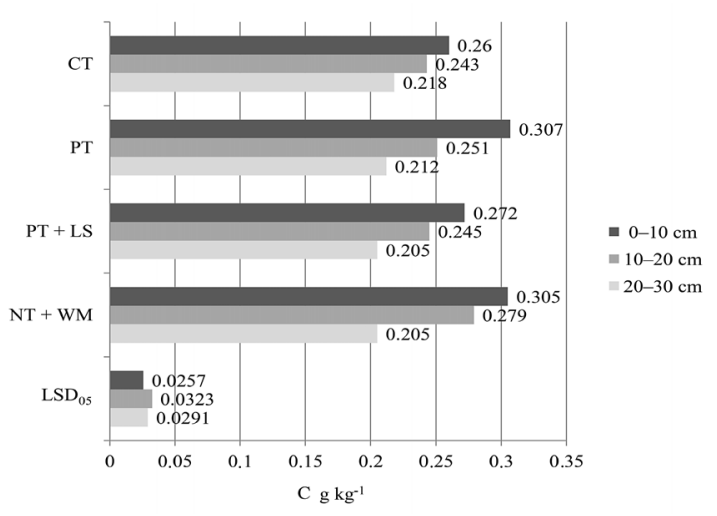

CT - conventional tillage, PT - ploughless tillage, PT + LS ploughless tillage with lime sludge incorporation, NT + WM - no-tillage with cover crop for winter mulch

Figure 2. The influenced of the tillage systems on labile organic carbon content in glaciolacustrine clay loam Eutric Endocalcaric Amphistagnic Endogleyic Cambisol (site III, 2017)

\section{Conclusions}

1. Long-term no-tillage (NT) resulted in pronounced soil organic carbon (SOC) and macronutrients stratification, increasing of SOC, total nitrogen $\left(\mathrm{N}_{\text {tot }}\right)$, available $\mathrm{K}_{2} \mathrm{O}$ within $0-30 \mathrm{~cm}$ top layer in morain Eutric Endocalcaric Endostagnic Cambisol (site I). NT superiority over conventional tillage (CT) for SOC sequestration in loam reached $8 \%$ on the background without straw and $13 \%$ on the background with straw. However, in sandy loam top layer, NT had the advantage over CT only under straw removal - its superiority over $\mathrm{CT}$ for SOC sequestration reached 4\%. Meanwhile, under straw return, SOC sequestration was $16 \%$ higher in CT than NT.

2. Ploughless tillage with lime sludge (Caamendment) incorporation (PT + LS) had the highest potential for SOC accumulation in clay loam top layer of glaciolacustrine Eutric Endocalcaric Amphistagnic Endogleyic Cambisol (site III). It significantly increased the fraction of humified Ca-bound $\mathrm{C}$ in $0-10$ and 10 $20 \mathrm{~cm}$ layers, compared to CT. Due to the application of ploughless tillage (PT), the soil stratified into layers according to the concentration of labile organic $\mathrm{C}$.

3. Soil $\mathrm{C}$ distribution in chemodestructive fractions was more evident in sandy loam top layer Eutric Endocalcaric Endostagnic Cambisol (site I) - the mean results of $0-30 \mathrm{~cm}$ layer revealed that $\mathrm{C}$ content in easily oxidizable F1, F2 and relatively stable F3 fractions was lower under NT, while percent of resistant F4 fraction was significantly higher under NT than under CT. However, the distribution of $\mathrm{C}$ in fractions of different stability was most influenced by soil genesis. The results of our study showed that $\mathrm{C}$ transformation in the soil and chemical composition of the soil reflect this transformation, depending on soil management applied and the inherent properties of the soil itself.

4. The highest accumulation of SOC as well as chemically protected-humified $\mathrm{C}$ in a sandy loam top layer of glacial morain Endocalcaric Albic Brunic Endogleyic Arenosol (site II) used as grassland was determined at the highest digestate rate of $170 \mathrm{~kg}$ $\mathrm{ha}^{-1} \mathrm{~N}$, which showed that it was not only important as a biofertiliser for plants, but also as a potential soil improver promoting accumulation of SOC and $\mathrm{C}$ of mobile humic acids.

5. The results of our study suggest that with decreasing tillage intensity in a clay loam top layer Eutric Endocalcaric Amphistagnic Endogleyic Cambisol (site III) the concentration of labile organic $\mathrm{C}$ in the soil, especially in the upper $0-10 \mathrm{~cm}$ layer increased by $0.307 \mathrm{~g} \mathrm{~kg}^{-1}$ under PT and $0.305 \mathrm{~g} \mathrm{~kg}^{-1}$ under NT with a cover crop for winter mulch (NT $+\mathrm{WM})$. The lime sludge application reduced the amount of labile organic $\mathrm{C}$, while increasing the stability of $\mathrm{C}$ compounds. The concentrations of labile organic $\mathrm{C}$ decreased with increasing soil depth. 


\section{Acknowledgements}

The first author as a project leader acknowledges the project "Quality diagnostics of biogas production byproduct (digestate) for innovative use as a biofertilizer" No. DOTSUT-217(01.2.2-LMT-K-718-01-0053) funded by the Research Council of Lithuania.

Received 07102019

Accepted 10072020

\section{References}

1. Amalevičiūtė K., Šlepetienė A., Liaudanskienė I., Slepetys J. 2014. Chemical composition of peat bog soil and its influencing factors. Zemès ūkio mokslai / Agricultural Sciences, 21 (1): 1-8 (in Lithuanian) https://doi.org/10.6001/zemesukiomokslai.v21i1.2850

2. Awale R., Emeson M. A., Machado S. 2017. Soil organic carbon pools as early indicators for soil organic matte stock changes under different tillage practices in Inland Pacific Northwest. Frontiers in Ecology and Evolution, 5: 96. https://doi.org/10.3389/fevo.2017.00096

3. Bogužas V., MikučionienèR., ŠlepetienèA., Sinkevičienė A., Feiza V., Steponavičienè V., Adamavičienè A. 2015. Longterm effect of tillage systems, straw and green manure combinations on soil organic matter. ZemdirbysteAgriculture, 102 (3): 243-250. https://doi.org/10.13080/z-a.2015.102.031

4. Chabbi A., Lehmann J., Ciais P., Loescher H. W. Cotrufo M.F., Don A., SanClements M., Schipper L., Six J., Smith P., Rumpel C. 2017. Aligning agriculture and climate policy. Nature Climate Change, 7: 307-309. https://doi.org/10.1038/nclimate3286

5. Dijkstra F. A., Cheng W. 2007. Interactions between soil and tree roots accelerate long-term soil carbon decomposition. Ecology Letters, 10: 1046-1053. https://doi.org/10.1111/j.1461-0248.2007.01095.x

6. Feiziene D., Feiza V., Slepetiene A., Liaudanskiene I., Kadziene G., Deveikyte I., Vaideliene A. 2011. Long-term influence of tillage and fertilization on net carbon dioxide exchange rate on two soils with different textures. Journal of Environmental Quality, 40 (6): 1787-1796. https://doi.org/10.2134/jeq2011.0180

7. Feiziene D., Feiza V., Povilaitis V., Putramentaite A. Janusauskaite Daiva, Seibutis V., Slepetys J. 2016. Soil sustainability changes in organic crop rotations with diverse crop species and the share of legumes. Acta Agriculturae Scandinavica, Section B: Soil and Plant Science, 66 (1): 36-51. https://doi.org/10.1080/09064710.2015.1063683

8. Feiziene D., Feiza V., Karklins A., Versuliene A., Janusauskaite D., Antanaitis S. 2018. After-effects of longterm tillage and residue management on topsoil state in Boreal conditions. European Journal of Agronomy, 94: 12-24. https://doi.org/10.1016/j.eja.2018.01.003

9. Feng W. 2012. Testing the soil carbon saturation theory: maximal carbon stabilization and soil organic matter stability as a function of organic carbon inputs: doctor dissertation. University of Pennsylvania, USA, $173 \mathrm{p}$.

10. Geraei D.S., Hojati S., Landi A., Cano A. F. 2016. Total and labile forms of soil organic carbon as affected by land use change in southwestern Iran. Geoderma Regional, 7: 29-37. https://doi.org/10.1016/j.geodrs.2016.01.001

11. IPCC. 2001. Climate Change 2001. Contribution of Working Group 1 to the $3^{\text {rd }}$ Assessment Report of the Intergovernmental Panel on Climate Change. Cambridge University Press, $881 \mathrm{p}$

12. Jakhar R. R., Yadav S. R., Jakhar R. K., Devra P., Ram H., Kumar R. 2017. Potential and importance of carbon sequestrations in agricultural soils. International Journal of Current Microbiology and Applied Sciences, 6 (2): 17761788. https://doi.org/10.20546/ijcmas.2017.602.199

13. Jankauskas B., Jankauskiene G., Slepetiene A., Fullen M. A. Booth C. A. 2006 (a). International comparison of analytical methods of determining the soil organic matter content of Lithuanian Eutric Albeluvisols. Communications in Soil Science and Plant Analysis, 37: 707-720. https://doi.org/10.1080/00103620600563499

14. Jankauskas B., Slepetiene A., Jankauskiene G. Fullen M. A. Booth C. A. 2006 (b). A comparative study of analytical methodologies to determine the soil organic matter content of Lithuanian Eutric Albeluvisols. Geoderma, 136 (3-4) 763-773. https://doi.org/10.1016/j.geoderma.2006.05.015

15. Jokubauskaite I., Amaleviciute K., Lepane V., Slepetiene A., Slepetys J., Liaudanskiene I., Karcauskiene D., Booth C. A 2015. High-performance liquid chromatography (HPLC)size exclusion chromatography (SEC) for qualitative detection of humic substances and dissolved organic matter in mineral soils and peats in Lithuania. International Journal of Environmental Analytical Chemistry, 95 (6): 508-519. https://doi.org/10.1080/03067319.2015.1048435

16. Jokubauskaite I., Karčauskienė D., Slepetiene A. Repsiene R., Amaleviciute K. 2016. Effect of different fertilization modes on soil organic carbon sequestration in acid soils. Acta Agriculturae Scandinavica, Section B: Soil and Plant Science, 66 (8): 647-652. https://doi.org/10.1080/09064710.2016.1181200

17. Klute A. 1986. Methods of soil analysis. Part 1. Physical and Mineralogical Methods ( $2^{\text {nd }}$ ed.). American Society of Agronomy. https://doi.org/10.2136/sssabookser5.1.2ed

18. Kolář L., Kužel S., Horáček J., Čechová V., Borová-Batt J., Peterka J. 2009. Labile fractions of soil organic matter, their quantity and quality. Plant, Soil and Environment, 55 (6): 245-251. https://doi.org/10.17221/87/2009-PSE

19. Lal R. 2003. Global potential of soil carbon sequestration to mitigate the greenhouse effect. Critical Reviews in Plant Sciences 22 (2): 151-184.https://doi.org/10.1080/713610854

20. Lal R. 2018. Digging deeper: a holistic perspective of factors affecting soil organic carbon sequestration in agroecosystems. Global Change Biology, 24 (8): 3285-3301. https://doi.org/10.1111/gcb.14054

21. Lehmann J., Kleber M. 2015. The contentious nature of soil organic matter. Nature, 528: 60-68. https://doi.org/10.1038/nature16069

22. Leifeld J., Bassin S., Fuhrer J. 2005. Carbon stocks in Swiss agricultural soils predicted by land-use, soil characteristics, and altitude. Agriculture, Ecosystems and Environment, 105 (1-2): 255-266. https://doi.org/10.1016/j agee 2004.03.006

23. Liaudanskiene I., Slepetiene A., Velykis A., Satkus A. 2013. Distribution of organic carbon in humic and granulodensimetric fractions of soil as influenced by tillage and crop rotation. Estonian Journal of Ecology, 62 (1): 53-69. https://doi.org/10.3176/eco.2013.1.05

24. Liaudanskienè I., Šlepetienè A., Šlepetys J., Stukonis V. 2013. Evaluation of soil organic carbon stability in grasslands of protected areas and arable lands applying chemo-destructive fractionation. Zemdirbyste-Agriculture, 100 (4): 339-348. https://doi.org/10.13080/z-a.2013.100.043

25. Mažvila J. Staugaitis G. Kutra G. J. Jankauskas B. 2010. Application of empirical models for assessing the erodibility of Lithuanian soils. Žemès ūkio mokslai, 17 (3-4): 69-78 (in Lithuanian).

26. Mobley M. L., Lajtha K., Kramer M. G., Bacon A. R., Heine P. R., Richter D. D. 2015. Surficial gains and subsoil losses of soil carbon and nitrogen during secondary forest development. Global Change Biology, 21: 986-996. https://doi.org/10.1111/gcb.12715

27. Nikitin B. A. 1999. Methods for soil humus determination. Agro Chemistry, 3 (2): 156-158 (in Russian).

28. Ondrasek G., Bakić Begić H., Zovko M., Filipović L., Meriño-Gergichevich C., Savić R., Rengel Z. 2019. Biogeochemistry of soil organic matter in agroecosystems \& environmental implications. Science of the Total Environment, 658: 1559-1573. https://doi.org/10.1016/j.scitotenv.2018.12.243

29. O'Rourke S. M., Angers D. A., Holden N. M., McBratney A. B. 2015. Soil organic carbon across scales. Global Change Biology, 21 (10): 3561-3574. https://doi.org/10.1111/gcb.12959

30. Paustian K., Lehmann J., Ogle S., Reay D., Robertson G. P., Smith P. 2016. Climate-smart soils. Nature, 532: 49-57. https://doi.org/10.1038/nature17174

31. Ponomareva V. V., Plotnikova T. A. 1980. Humus and soil formation. Leningrad, 198 p. (in Russian).

32. Popov A. I., Tcyplenkov V. P. 1994. Sankt-Peterburg State University. Method of determination of humus forms. Patent of Russian Federation No. 2020481 (in Russian).

33. Popov A. I, Rusakov A. V., Nadporozhskaja M. A. Yakovleva V. V. 2004. The use of the chemodestruction fractionating for the estimation of quantitative-qualitative composition of soil organic matter. Humus and soilforming: collection of scientific works of St. Petersburg State Agrarian University, p. 63-72 (in Russian).

34. Schulz E. 2004. Influence of site conditions and management on different soil organic matter (SOM) pools. Archives of Agronomy and Soil Science, 50: 33-47. https://doi.org/10.1080/03650340310001627577

35. Six J., Callewaert P., Lenders S., De Gryze S., Morris S. J., Gregorich E. G., Paul E. A., Paustian K. 2002. Measuring and understanding carbon storage in afforested soils by physical fractionation. Soil Science Society of America Journal, 66: 1981-1987.

https://doi.org/10.2136/sssaj2002.1981 
36. Slepetiene A., Slepetys J., Liaudanskiene I., Kadziuliene Z., Velykis A., Adamovics A. 2011. Changes of soil organic carbon and mobile humic acids in response to different agricultural management. Agraarteadus. Journal of Agricultural Science, 22 (2): 64-70.

37. Slepetiene A., Staugaitis Z., Tilvikiene V., Slepetys J., Kadziuliene Z. 2017. The effect of mineral fertilizers and biogas digestate used for cocksfoot fertilization on the soil nitrogen changes. Fresenius Environmental Bulletin, 26 (4): 2604-2608.

38. Sleutel S., De Neve S., Nemeth T., Toth T., Hofman G. 2006. Effect of manure and fertilizer application on the distribution of organic carbon in different soil fractions in long-term field experiment. European Journal of Agronomy, 25: 280-288. https://doi.org/10.1016/j.eja.2006.06.005

39. Smith P., Soussana J.-F., Angers D., Schipper L., Chenu C., Rasse D. P., Batjes N.H., van Egmond F., McNeill S., Kuhnert M., Arias-Navarro C., Olesen J. E., Chirinda N., Fornara D., Wollenberg E., Álvaro-Fuentes J., SanzCobena A., Klumpp K. 2020. How to measure, report and verify soil carbon change to realize the potential of soil carbon sequestration for atmospheric greenhouse gas removal. Global Change Biology, 26 (1): 219-241. https://doi.org/10.1111/gcb.14815

40. Staugaitis Ž., Slepetiene A., Tilvikienė V., Kadžiulienė Ž 2016. The influence of cocksfoot fertilization with mineral fertilizers and digestate on total and labile carbon in the soil. Žemès ūkio mokslai /Agricultural Sciences, 23 (3): 123-129 (in Lithuanian).

https://doi.org/10.6001/zemesukiomokslai.v23i3.3359

41. Stockmann U., Adams M. A., Crawford J. W., Field D. J., Henakaarchchi N., Jenkins M., Minasny B., McBratney A. B., de Remy de Courcelles V., Singh K.,
Wheeler I., Abbott L., Angers D. A., Baldock J., Bird M., Brookes P. C., Chenu C., Jastrow J. D., Zimmermann M. 2013. The knowns, known unknowns and unknowns of sequestration of soil organic carbon. Agriculture, Ecosystems and Environment, 164: 80-99. https://doi.org/10.1016/j.agee.2012.10.001

42. Strosser E. 2010. Methods for determination of labile soil organic matter: an overview. Journal of Agrobiology, 27 (2): 49-60. https://doi.org/10.2478/s10146-009-0008-x

43. Volungevicius J., Amaleviciute-Volunge K., Versuliene A., Feiziene D., Feiza V., Slepetiene A., Liaudanskiene I., Vaisvalavicius R. 2018. The effects of agrogenic transformation on soil profile morphology, organic carbon and physico-chemical properties in Retisols of Western Lithuania. Archives of Agronomy and Soil Sciences, 64 (13): 1910-1923. https://doi.org/10.1080/03650340.2018.1467006

44. Volungevičius J., Fęiza V., Amalevičiūtè-Volungè K., Liaudanskienè I., Slepetienè A., Kuncevičius A., Vengalis R., Vèlius G., Prapiestienè R., Poškienè J.' 2019. Transformations of different soil under natural and anthropogenized land management. ZemdirbysteAgriculture, 106 (1): 3-14.

https://doi.org/10.13080/z-a.2019.106.00

45. Wiesmeier M., Urbanski L., Hobley E., Langc B., von Lützow M., Marin-Spiotta E., van Wesemaele B., Rabot E., Ließ M., Garcia-Franco N., Wollschläger U., Vogel H-J., Kögel-Knabner I. 2019. Soil organic carbon storage as a key function of soils - a review of drivers and indicators at various scales. Geoderma, 333: 149-162. https://doi.org/10.1016/j.geoderma.2018.07.026

46. WRB. 2014. World reference base for soil resources. World Soil Resources Reports No. 106. FAO, p. 187-189.

ISSN 1392-3196 / e-ISSN 2335-8947

Zemdirbyste-Agriculture, vol. 107, No. 4 (2020), p. 291-300

DOI 10.13080/z-a.2020.107.037

\title{
Dirvožemio organinės anglies, jos formų ir makroelementų pasiskirstymas žemès ūkio paskirties dirvožemiuose
}

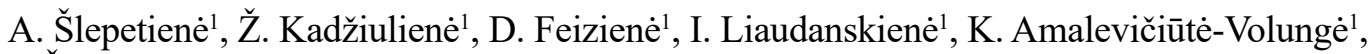 \\ J. Šlepetys ${ }^{1}$, A. Skersienè $\dot{e}^{1}$, A. Velykis ${ }^{2}$, K. Armolaitis ${ }^{3}$
}

${ }^{1}$ Lietuvos agrarinių ir miškų mokslų centro Žemdirbystės institutas

${ }^{2}$ Lietuvos agrarinių ir miškų mokslų centro Joniškèlio bandymų stoties

${ }^{3}$ Lietuvos agrarinių ir miškų mokslų centro Miškų institutas

\section{Santrauka}

Tyrimo tikslas - ivvertinti dirvožemio organinės anglies bei jos formų (apsaugotos ir labilios) ir suminio azoto $\left(\mathrm{N}_{\text {too }}\right)$, judriujų $\mathrm{P}_{2} \mathrm{O}_{5}$ bei $\mathrm{K}_{2} \mathrm{O}$ pasiskirstymą dirvožemio $0-30 \mathrm{~cm}$ sluoksnyje priklausomai nuo naudojimo - žemès dirbimo ir tręšimo. Tyrimas atliktas dviejuose šalies regionuose - centrinèje (I ir II vietovès) ir šiaurinèje (III vietovè) Vidurio Lietuvos žemumos dalyse. I vietovèje moreniniame vidutinio sunkumo priemolyje ir smèlingame lengvame priemolyje Eutric Endocalcaric Endostagnic Cambisol (Loamic, Aric, Drainic)) tirta tradicinis (skutimas + arimas) žemès dirbimas ir tiesioginè sèja, šiaudu panaudojimo būdai ir tręšimas mineralinèmis trąšomis. II vietovèje tirta trešimo ịtaka moreniniam smèlžemiui (Endocalcaric Albic Brunic Endogleyic Arenosol (Dystric)) penkių variantu bandyme: be trąšu, tręšiant separuotu skystu digestatu 85 ir $170 \mathrm{~kg} \mathrm{ha}^{-1} \mathrm{~N}$, tręšiant separuotu sausu digestatu 85 ir $170 \mathrm{~kg} \mathrm{ha}^{-1} \mathrm{~N}$. III vietoveje limnoglacialiniame sunkaus priemolio rudžemyje (Eutric Endocalcaric Amphistagnic Endogleyic Cambisol (Clayic, Aric, Drainic)) tirtos žemès dirbimo sistemos: tradicinė, neariminè, neariminè įterpus kalkių purvą ir be žemés dirbimo, tarpinius pasèlius palikus mulčiui per žiemą.

Ilgalaikis tradicinio žemès dirbimo atsisakymas priemolio dirvožemyje nulèmé suminio azoto, judriojo $\mathrm{K}_{2} \mathrm{O}$ ir dirvožemio organinès anglies stratifikaciją dirvožemio viršutiniuose sluoksniuose. Daugiausia organinès anglies ir chemiškai apsaugotos humifikuotos anglies žolyno dirvožemyje nustatyta patręšus didžiausia norma digestato (anaerobinio raugo) - $170 \mathrm{~kg} \mathrm{ha}^{-1} \mathrm{~N}$. Didelis organinès anglies sekvestravimo potencialas nustatytas sunkaus priemolio rudžemyje neariminị žemès dirbimą derinant su ịterptu kalkių purvu. Tai esmingai padidino su kalciu sujungtos humifikuotos anglies frakciją dirvožemio 0-10 ir 10-20 cm sluoksniuose, palyginus su tradiciniu arimu. Sunkaus priemolio rudžemyje žemès dirbimo intensyvumo sumažinimas, taikant neariminị dirbimą ir be žemès dirbimo, tarpinius pasèlius palikus mulčiui, padidino labilios anglies koncentraciją, ypač $0-10 \mathrm{~cm}$ sluoksnyje. Kalkių purvo panaudojimas sumažino labilios anglies kiekị ir kartu padidino dirvožemio organinės anglies stabilumą, jai susijungus su kalkių purve esančiu kalciu. Smèlingame lengvame priemolyje neariant $0-30 \mathrm{~cm}$ sluoksnyje chemodestrukciniam skaidymui atsparios F4 frakcijos anglies dalis buvo esmingai didesné, palyginus su tradicinio dirbimo taikymu.

Reikšminiai žodžiai: digestatas (anaerobinis raugas), kalkių purvas, labili ir apsaugota anglis, tręšimas, žemès dirbimas, dirvožemis. 